\title{
ゾルーゲル法によるナイロンフィルムへのシリカ薄膜の調製 +
}

\author{
塚 本 忠 和* 川 崎 元 夫** 山 根 秀 樹*
}

\section{Formation of the Silicate Layers on the Nylon 6 Film by Sol-Gel Method}

by

\author{
Tadakazu Tsukamoto ${ }^{*}$, Motoo Kawasaki ${ }^{* *}$ and Hideki Yamane ${ }^{*}$
}

\begin{abstract}
Silicate layer was prepared on the nylon 6 film by sol-gel method. Effect of reaction conditions on the various properties, such as layer thickness, surface morphology and the water vapor permeation rates were examined. Increasing sol-gel reaction time gives a increasing silicate layer thickness. However because of the roughness of the surface produced due to the 3-dimensional siloxane network formation in sol-gel reaction system occurred at a longer reaction time, the water vapor permeation rate was high. Addition of DMF in sol-gel reaction system controlled the drying of coated film and suppressed the shrinkage of silicate layer resulting in the smooth crack-free layers. When UV was irradiated on the sol-gel reaction system, the surface of the coated film was rather smooth and the coated film gave a fairly high barrier to water vapor, although the thickness of the layer was rather small.
\end{abstract}

Key words : Sol-gel method., Silicate layer, Nylon-6 film, Water vapor permeation, Surface morpholgy

\section{1 緒言}

ゾルーゲル法による酸化物薄膜の調製が近年様々な分 野で利用されている．無機材料分野では金属やガラスを 基板として調製されることが多い. ゾルーゲル法の特徴 として液相中でのアルコキシドの加水分解と重縮合の 2 つの反応により多孔質の酸化物を形成する. ${ }^{12}$ 従来から 薄膜作製に使用されている蒸着法と比較して低温で合成 できること，また原料を粘度の低い溶液中で反応させる 液相反応であるため分子レベルで均一に膜生成が可能で

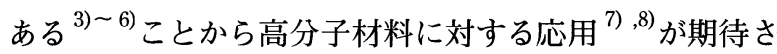
れてきた。

包装材料は高分子材料の用途の中で特に大きな割合を 占めているが，無機薄膜をコーティングすることで高い ガスバリアー性を持たせることができるものと期待され る. 高分子フィルムへの無機薄膜の形成は真空蒸着 ${ }^{9), 10)}$ や化学蒸着などですでに行われているが, 装置が大がか りなために生産コストが高くなる。本研究では大がかり な装置を必要としない手法としてゾルーゲル法を用いて ナイロン 6 フィルム上に酸化ケイ素膜をコーティングし， 汎用包装材料の中でも水蒸気透過度の高いナイロンフィ ルムの水蒸気に対するバリアー性の向上を試みた。ゾ ルーゲルプロセスにおける膜調製において加水分解，重 縮合反応条件やコーティング条件による酸化ケイ素膜の 膜厚, 表面特性, 水蒸気透過性の関係を検討した.

\section{2 実験}

\section{$2 \cdot 1$ 試 料}

$2 \cdot 1 \cdot 1$ フィルムの前処理 試料として厚さ $22.6 \mu \mathrm{m}$ のナイロンー 6 フィルム (東洋紡製) を使用した. 前処 理としてフィルムの洗浄を行った. 超音波洗浄器（ヤマ
八科学株式会社）により蒸留水中で超音波洗浄を 5 分間 行い, その後アセトンに 10 分間浸した後, エタノールと 蒸留水で十分に洗浄し乾燥した.

$2 \cdot 1 \cdot 2$ ゾル溶液の調製 出発物質として金属アル コキシドであるテトラエトキシシラン $\mathrm{Si}\left(\mathrm{OC}_{2} \mathrm{H}_{5}\right)_{4}$ (TEOS) を用いた。 また, 加水分解に必要な蒸留水との相溶性を 持つ溶媒としてエタノール $(\mathrm{EtOH})$ を選択した。触媒に は $6 \mathrm{~mol} / 1$ 塩酸 $(\mathrm{HCl})$ を使用した。 また乾燥抑制郕 ${ }^{1), 2)}$ としてジメチルフォルムアミド (DMF) を系に加え反応 溶液を調製した:

反応組成比（モル比）を TEOS : EtOH : $\mathrm{H}_{2} \mathrm{O}: \mathrm{HCl}$ ： $\mathrm{DMF}=1: 4: 4: 0.03: 1$ と TEOS $:$ EtOH $: \mathrm{H}_{2} \mathrm{O}:$ $\mathrm{HCl}: \mathrm{DMF}=1: 4: 8: 0.03: 1$ の二種類とし, これ以外 に上記の組成比で DMF を加えない系の計 4 種類で実験 を行った. 1 番目の組成の反応系ではTEOS104.15g にエ タノールを所定の半分量 $46.07 \mathrm{~g}$ を加えかく拌した. 更に DMF36.54g を加え混合した. 次に水 $36.03 \mathrm{~g}$ 打よび触媒で ある $\mathrm{HCl} 0.546 \mathrm{~g}$ を残りのエタノール $46.07 \mathrm{~g}$ に溶解し， TEOS, エタノール, DMF の混合液にかく拌しながら滴 下した. 反応温度は $40^{\circ} \mathrm{C}$ と, 1 時間, 2 時間, 5 時間か く找した，反応は窒素ガス䨌囲気下で行った。 その後, 系を容器に移し常温になるまで室温で 2 時間静置した.

$2 \cdot 1 \cdot 3$ コーティング ディップコーティング法 ${ }^{11)}$ を使用した. 調製したゾル溶液にフィルムを一分間浸し, 静止した状態からモーターにより，0.5mm/s および 1.0 $\mathrm{mm} / \mathrm{s}$ の 2 種類の速度で引き上げた. さらにディップコ 一ティングしたフィルムを 1 時間室温で空気中に放置し た後, $50^{\circ} \mathrm{C}$ で最大 20 時間加熱した.

$2 \cdot 1 \cdot 4$ 紫外線照射プロセス ゾルーゲル反応は

$\dagger$ 原稿受理 平成 14 年 3 月 11 日 Received Mar. 11, 2002

* 正 会 員 京都工芸繊維大学工芸科学研究科先端ファイブロ科学専攻 †606-8585 京都市左京区松ヶ崎御所海道町, Division of Advanced FibroSci., Kyoto Inst. of Tech., Sakyo-ku, Kyoto, 606-8585

** 川崎技術士事務所 T601-1334 京都市伏見区醍醐勝口町, Kawasaki Registed Technical Consulting Office, Fushimi-ku, Kyoto, 601-1334 
$100{ }^{\circ} \mathrm{C}$ 以下の低温でも反応が進行するが，その反応速 度は非常に低い。 また高温では基板のポリマーフィルム に影響を及ぼすおそれがある。一方，紫外線を照射する ことにより低温でも重縮合反応を促進させることができ る. ${ }^{12), 13)}$ 本研究では, ゾル溶液およびディップコーティ ングしたフィルムに波長 $254 \mathrm{~nm}$ の紫外線を $10 〜 90 \mathrm{~min}$ 照射した。紫外線照射装置には UM-100B (USHIO ELECTRIC INC) を使用した，金属製の箱の中央に紫外 線ランプを設置し, 紫外線ランプ周辺に等距離となるよ うにコーティングフィルムまたは調製溶液を置いて紫外 線を照射した。

\section{$2 \cdot 2$ 測定と観察}

$2 \cdot 2 \cdot 1$ 表面の化学分析 フィルムの表面分析は FTIR 透過法により行った. 測定はFT-IR スペクトロメータ 一 JIR-WINSPEC50 (JEOL. CO. Ltd) を用いた.

$\mathbf{2} \cdot \mathbf{2} \cdot \mathbf{2}$ 膜厚測定 コーティングした膜の厚さを灰 化重量試験 ${ }^{14)}$ により測定した. $10 \mathrm{~cm}^{2}$ のサンプルをるつ ぼに入れ， $600^{\circ} \mathrm{C} て ゙ 2$ 時間かけて灰化させ，単位面積あ たりの灰分の重量を測定した. 得られたシリカ膜 $\left(\mathrm{SiO}_{2}\right)$ の重量を SiO に換算し膜厚を求めた。換算は以下の式を 用いた。

$$
h=\frac{W \times\left(M_{S i o} / M_{S i O_{2}}\right) \times 10^{8}}{S \times \rho}
$$

ここで $h$ はコーティング膜の膜厚 $(\AA), W$ は灰分の重 量 $(\mathrm{g}), S$ はサンプルの面積 $\left(\mathrm{cm}^{2}\right), \rho$ は $\mathrm{SiO}$ の密度 $(\mathrm{g} /$ $\left.\mathrm{cm}^{3}\right), M_{\mathrm{SiO} O}$ と $M_{\mathrm{SiO} 2}$ はとれぞれ $\mathrm{SiO}$ と $\mathrm{SiO}_{2}$ の分子量で ある. $\mathrm{SiO}$ の密度は $2.18 \mathrm{~g} / \mathrm{cm}^{3}$ とした。

$2 \cdot 2 \cdot 3$ 接触角測定 コーティングフィルムの表面 状態を知るために接触角を CONTACT-ANGLE METER CA-A (KYOWA SCIENTIFIC CO. LTD)を用いて測定し た. フィルムサンプルをガラス板上に固定し, 蒝留水に 対する前進接触角を室温で測定した。

$2 \cdot 2 \cdot 4$ 表面モルフォロジー観察 コーティングフ イルムの表面モルフォロジーを原子間力顕微鏡 AFM Nano Scope III a（デジタル インスッルメント社）に より観察した.タッピングモードを用い, Scan size $10 \mu \mathrm{m}$, Scan rate $1.00 \mathrm{~Hz}$, 最大深度 $20 \mathrm{~nm}, 300 \mathrm{~nm}$ で観察した.

$2 \cdot 2 \cdot 5$ 水蒸気透過試験 コーティングフィルムの 水蒸気透過性 ${ }^{15)}$ は JIS 規格 Z208 防湿包装材料の透湿試 験方法 (カップ法 $)^{16)}$ を参考にして測定した. 直径 $10 \mathrm{~cm}$ のポリスチレン製シャーレに $20 \mathrm{~g}$ の乾燥剤（シリカゲル， 球状， 6 mesh up）を入れ，コーティングフィルムで覆っ た.フィルムとシャーレとは信越シリコーン RTV ゴム (信越化学) で接着した. ガラス製のデシケータ内を温度 $20^{\circ} \mathrm{C}$, 湿度 $95 \mathrm{RH}$ に保持し, 重量を測定したサンプルを 入れ, 24 時間, 48 時間, 72 時間後の重量の変化を測定 した。 相対湿度は飽和塩水溶液法 ${ }^{17)} に よ り$ 設定した。水 蒸気透過度の算出は以下の式を用いて求めた。

$$
p\left(g / m^{2} \cdot 24 h\right)=\frac{240 \times m}{t \times S}
$$

ここで $p$ は透湿度, $s$ は透湿面積 $\left(\mathrm{cm}^{2}\right), t$ は試験を行 った二つの秤量間隔の時間の合計 $(h), m$ は試験を行っ た二つの秤量間隔增加重量の合計 $(\mathrm{mg})$ とした.

\section{3 結果と考察}

ゾルーゲル反応系に DMF を添加しない場合, 調製し たゾル溶液は無色透明で均一であり, コーティング後の フィルム表面も調製溶液同様，無色透明で均一であった。 また DMFを添加した場合も調製したゾル溶液、コーテ イング後のフィルム表面ともに無色透明で均一であった。 しかし, ナイロンフィルム上にゾル溶液をコーティング した後,フィルムに紫外線を照射した場合, 紫外線を照 射しない場合と比較すると膜表面がざらつきのある不均 一なものとなった。一方，ゾル溶液に紫外線照射したと ころゾル溶液は無色透明で均一であり，そのゾル溶液を 用いたコーティング膜表面も無色透明で均一であった. 従って，以下ではゾル溶液への紫外線照射の影響につい て検討する.

\section{$3 \cdot 1$ 表面分析}

Fig. 1 に基板であるナイロンフィルムおよびコーティ ングフィルムの FT-IR 透過スペクトルを示す. 組成比は TEOS : EtOH $: \mathrm{H}_{2} \mathrm{O}: \mathrm{HCl}: \mathrm{DMF}=1: 4: 4: 0.03: 1$, 反応時間が $5 h$ ，引き上げ速度が $1.0 \mathrm{~mm} / \mathrm{s}$ である。この 図から Si-O-Si のシロキサン結合を示す特性吸収帯が $1000 \sim 1100 \mathrm{~cm}^{-1}$ 付近に存在することがわかる. ゾルー ゲル法によって得られる酸化ケイ素からは1000 $1100 \mathrm{~cm}^{-1}$ 付近に $\mathrm{Si}-\mathrm{O}-\mathrm{Si}$ のシロキサン結合の伸縮振動に よる吸収帯および, $3000 \sim 3400 \mathrm{~cm}^{-1}$ 付近に $\mathrm{Si}-\mathrm{OH}$ のシ ラノール基による伸縮振動が見られる ${ }^{18), 19)}$ が，ナイロ ンの $3100 \mathrm{~cm}^{-1}$ 付近の水素結合による吸収帯と重なって しまう. 従って, $1000 \sim 1100 \mathrm{~cm}^{-1}$ 付近に観察される $\mathrm{Si}-$ $\mathrm{O}-\mathrm{Si}$ のシロキサン結合の伸縮振動の吸収帯により反応の 進行について検討した。

Fig. 2 に反応時間に伴う $\mathrm{SiO}_{2}$ 生成量の変化を $1650 \mathrm{~cm}^{-1}$ 付近のアミド結合の伸縮振動の強度に対する $1100 \mathrm{~cm}^{-1}$ 付近に現れるシロキサン結合の強度の比として 示す. DMFは添加していない，この図より水分率とと もに吸収強度は低くなっていることがわかる，また，引 き上げ速度の上昇とともに吸収強度が高くなった。組成 比が TEOS: EtOH : $\mathrm{H}_{2} \mathrm{O}: \mathrm{HCl}: \mathrm{DMF}=1: 4: 4:$ $0.03: 1$ の場合, $\mathrm{pH}$ の值は 1.5 であったが, TEOS :

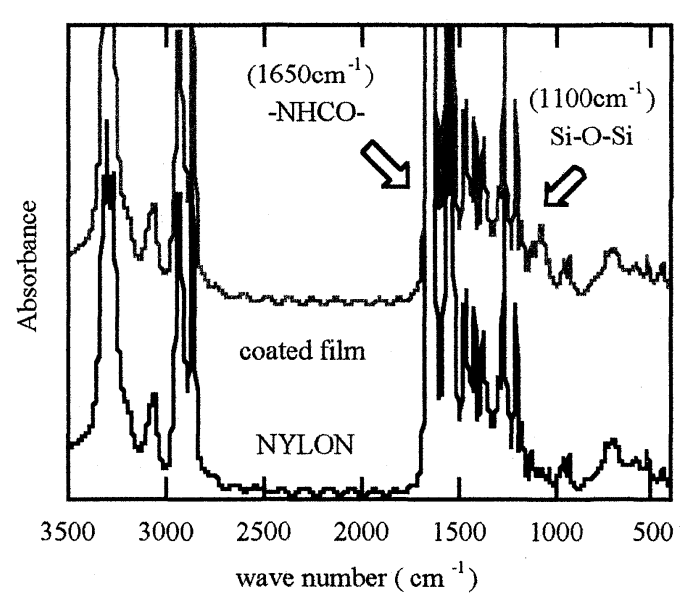

Fig. 1. FT-IR spectra of nylon and silica coated films. 


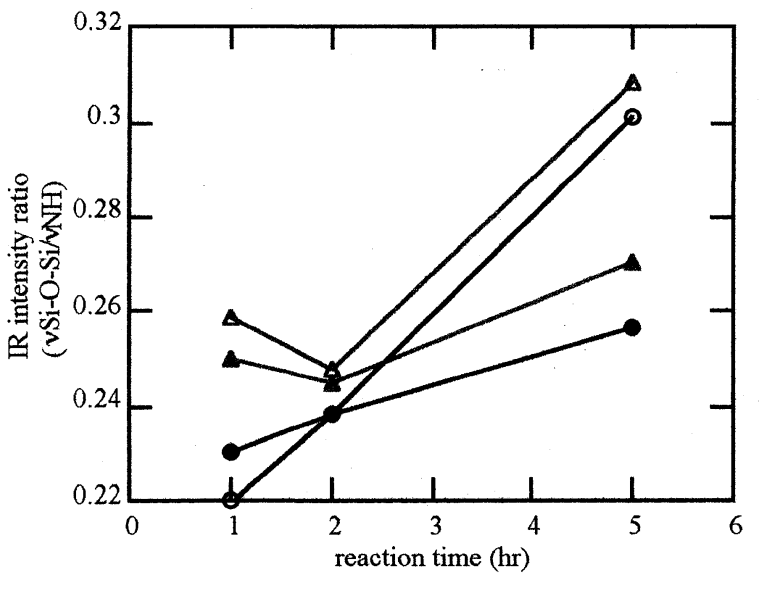

Fig. 2. IR Intensity ratio of siloxane $\left(1100 \mathrm{~cm}^{-1}\right)$ to amide $\left(1650 \mathrm{~cm}^{-1}\right)$ as functions of reaction time.

TEOS:EtOH: $\mathrm{H}_{2} \mathrm{O}: \mathrm{HCl}=1: 4: 4: 0.03$, drawing rate $0.5 \mathrm{~mm} / \mathrm{s}$ - TEOS:EtOH: $\mathrm{H}_{2} \mathrm{O}: \mathrm{HCl}=1: 4: 8: 0.03$, drawing rate $0.5 \mathrm{~mm} / \mathrm{s}$ $\triangle$ TEOS:EtOH:H $2 \mathrm{O}: \mathrm{HCl}=1: 4: 4: 0.03$, drawing rate $1.0 \mathrm{~mm} / \mathrm{s}$

A TEOS:EtOH: $\mathrm{H}_{2} \mathrm{O}: \mathrm{HCl}=1: 4: 8: 0.03$, drawing rate $1.0 \mathrm{~mm} / \mathrm{s}$

EtOH $: \mathrm{H}_{2} \mathrm{O}: \mathrm{HCl}: \mathrm{DMF}=1: 4: 8: 0.03: 1$ の場合, $\mathrm{pH}$ の值は 2.1 となった。加水分解に使用する水分率を増 加させることで希釈され，反応系の酸濃度が低くなり加 水分解速度を若干遅くするために単位時間あたりに生成 される生成シラノール量が少なくなったと考えられる. 加水分解反応では酸触媒はオキソニウムイオンを生成し 求電子反応させるため, 酸濃度の低下はオキソニウムイ オン生成量の減少となるため加水分解速度が低下すると 考えられ，そのため重合によるシロキサン生成量が減少 し吸収強度が低くなったと考えられる。

Fig. 3 には反応時間に伴う $\mathrm{SiO}_{2}$ 生成量の変化に対す る DMF 添加の影響を示している．引き上げ速度一定の 場合，DMFを添加しない系よりも DMF を添加した方が コーティング膜のシロキサン吸収強度が低いことがわか る。また，引き上げ速度が速いほど吸収強度が高くなる ことがわかる.

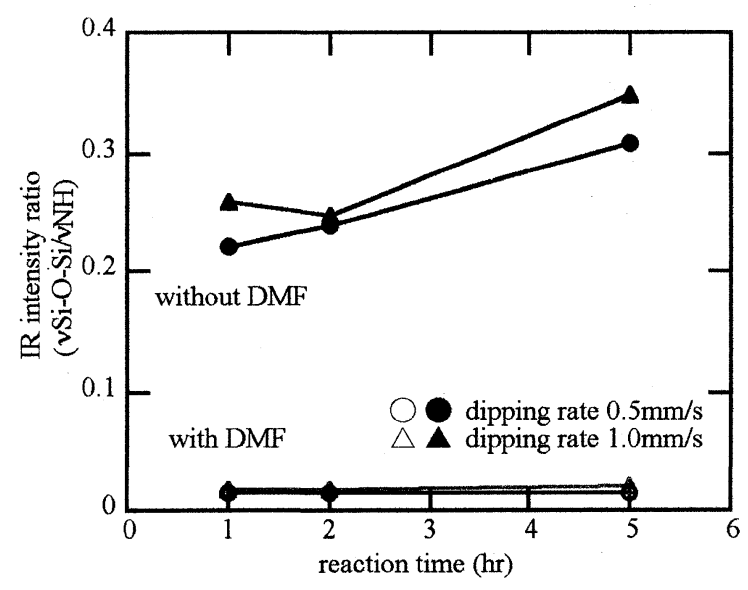

Fig. 3. IR Intensity ratio of siloxane $\left(1100 \mathrm{~cm}^{-1}\right)$ to amide $\left(1650 \mathrm{~cm}^{-1}\right)$ as functions of reaction time.

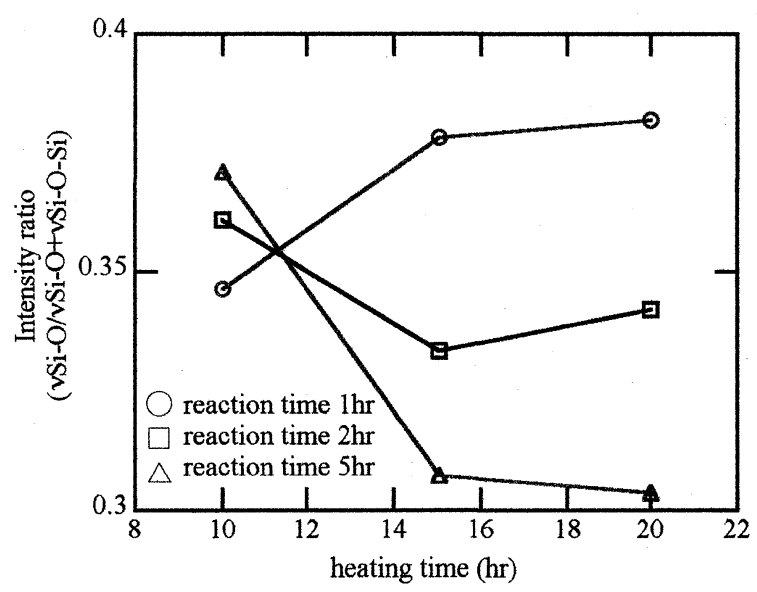

Fig. 4. Intensity ratio of $\mathrm{SiO}\left(980 \mathrm{~cm}^{-1}\right)$ to total siloxane $\left(980 \mathrm{~cm}^{-1}+1100 \mathrm{~cm}^{-1}\right)$ as functions of heating time at various temperatures after coating.

Fig. 4 にはコーティング後の加熱時間による反応進行 状況について反応組成比が TEOS : EtOH $: \mathrm{H}_{2} \mathrm{O}: \mathrm{HCl}$ ： $\mathrm{DMF}=1: 4: 4: 0.03: 1$, 引き上げ速度が $1.0 \mathrm{~mm} / \mathrm{s}$ の ものについて示している. ゾルーゲル反応に伴うシロキ サン結合の吸収は $1100 \mathrm{~cm}^{-1}$ 付近に現れるが, これは $\mathrm{SiO}_{2}$ に由来するものであり, 同じ酸化ケイ素に属する $\mathrm{SiO}$ はやや低波長側の $980 \mathrm{~cm}^{-1}$ に吸収がシフトされるこ とが $\mathrm{E} \cdot \mathrm{Ritter}^{20)}$ によって報告されている. 生成したシラ ノールは $\mathrm{SiO}_{2}$ に変化するまでに中間反応生成物として $\mathrm{SiO}$ になると考えられる。 そこで全酸化ケイ素 $(\mathrm{SiO}+$ $\left.\mathrm{SiO}_{2}\right)$ に対する $\mathrm{SiO}$ の吸収強度の割合を求め, プロット したものを Fig. 4 に示す. ゾルーゲル反応時間が 1 時間 の場合, SiO の割合は加熱時間の增加に伴って増加して いる. 一方, 反応時間が 2 時間以上では $S i O$ の割合は低 下しており, 加熱時間の増加とともに $\mathrm{SiO}$ がさらに酸化 されて $\mathrm{SiO}_{2}$ へと変化すると考えられる.

次に，紫外線照射の影響について示す. Fig. 5 に紫外 線照射したゾル溶液をコーティングしたフィルムの FTIR 透過スペクトルを示す. ゾルーゲル反応により生成さ

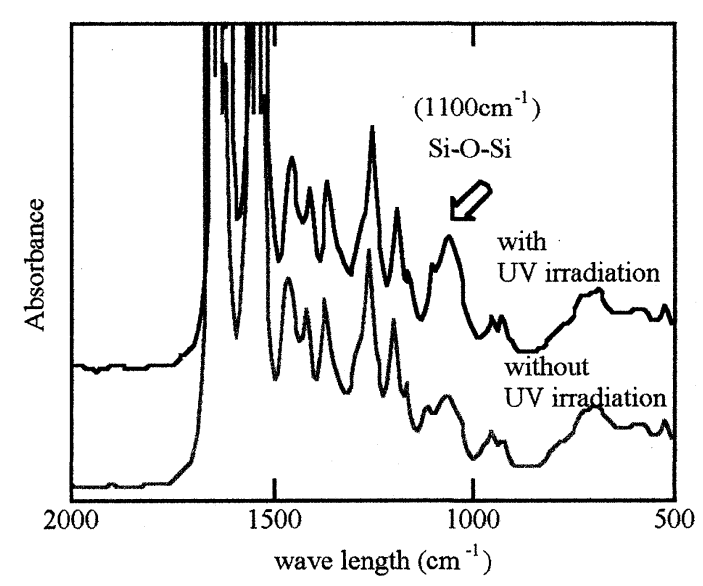

Fig. 5. FT-IR spectra of silica coated films with and without UV irradiation. 
れるシロキサン結合を示す特性吸収帯が 1000 ～1100 $\mathrm{cm}^{-1}$ 付近に観察されるが，紫外線を照射した場合にはその 吸収強度が顕著に増大し, 反応が進行していることがわ かる.

全酸化ケイ素 $\left(\mathrm{SiO}+\mathrm{SiO}_{2}\right)$ に対する $\mathrm{SiO}$ の吸収強度比 を Fig. 6 に示したが，紫外線照射時間の増大とともに 徐々にSiO の吸収強度が低下していることがわかる. 60 分間の紫外線照射により吸収強度が約 $40 \%$ 低下すること から，柴外線照射下での重合反応は非常に速く進行して いるものと考えられ，加水分解により生成したシラノー ル基が紫外線により $\mathrm{SiO}$ ラジカルを生成し, 重合が進行 したものと思われる.

Fig. 7 には紫外線照射時間に対するコーティングフィ ルムの水に対する接触角の変化を示す．紫外線照射時間 の増加とともに接触角が増大していることが確認できる. これは表面のシラノールが紫外線照射により $\mathrm{SiO}$ に変化

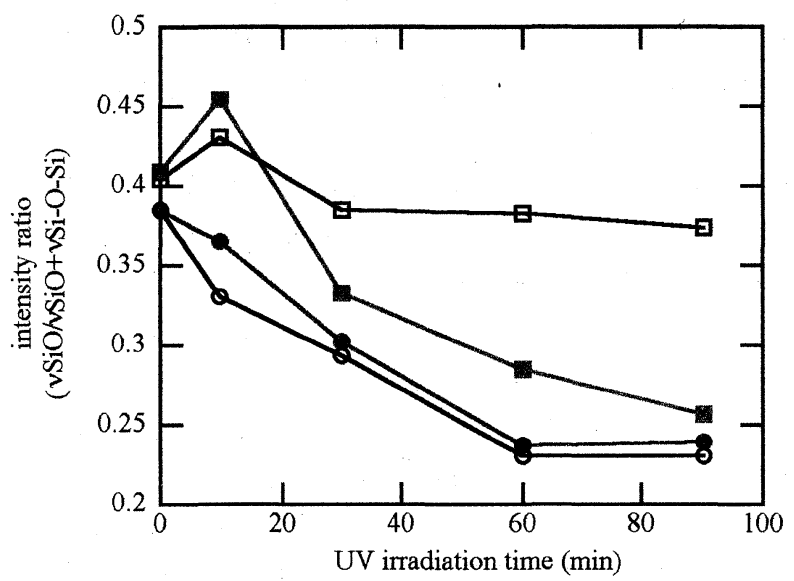

Fig. 6. IR Intensity ratio of siloxane $\left(1100 \mathrm{~cm}^{-1}\right)$ to amide $\left(1650 \mathrm{~cm}^{-1}\right)$ as functions of UV irradiation time.

TEOS:EtOH:H $\mathrm{H}_{2} \mathrm{O}: \mathrm{HCl}: \mathrm{DMF}=1: 4: 4: 0.03: 1$, drawing rate $0.5 \mathrm{~mm} / \mathrm{s}$ TEOS:EtOH:H $\square$ TEOS:EtOH:H $\mathrm{H}_{2} \mathrm{O}: \mathrm{HCl}: \mathrm{DMF}=1: 4: 8: 0.03: 1$, drawing rate $0.5 \mathrm{~mm} / \mathrm{s}$ TEOS:EtOH:H $\mathrm{H}_{2} \mathrm{O}: \mathrm{HCl}: \mathrm{DMF}=1: 4: 8: 0.03: 1$, drawing rate $1.0 \mathrm{~mm} / \mathrm{s}$

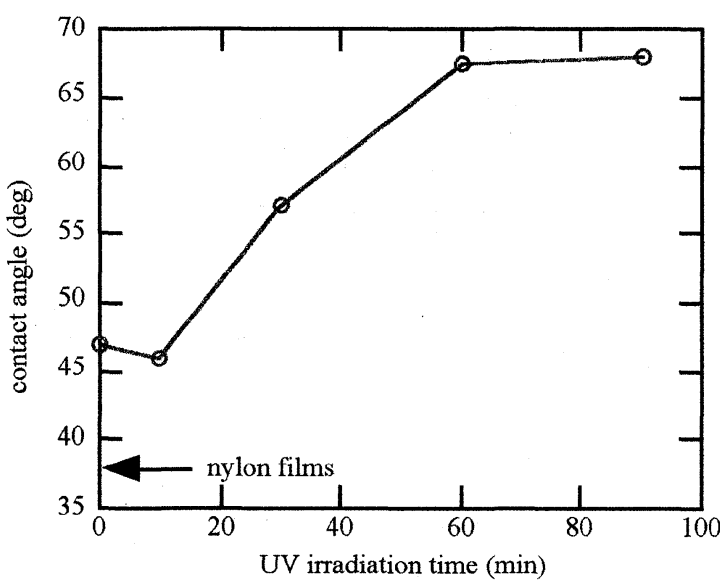

Fig. 7. Contact angle of water to silicate coated films as a function of UV irradiation time.
していることが原因と考えられる。

\section{$3 \cdot 2$ 酸化ケイ素膜厚}

Fig. 8 は膜厚のゾルーゲル反応時間および引き上げ速 度依存性を組成比別に示したものである。この図より加 水分解に使用する水の量を増加させると膜厚が薄くなる こと, 引き上げ速度の増加と共に膜が厚くなることがわ かる，また，反応時間が長くなると重合が進行し，ポリ シロキサン量が増大するため膜厚は厚くなる。さらに DMF を含む場合には膜厚が薄いことがわかる.

Fig. 9 は紫外線照射時間と膜厚との関係を示してい る。紫外線照射時間の増加に伴ってコーティング膜の膜 厚が急激に増加した。この結果は紫外線照射により重合 が非常に速く進行し溶液中の粘度が上昇するためにコー

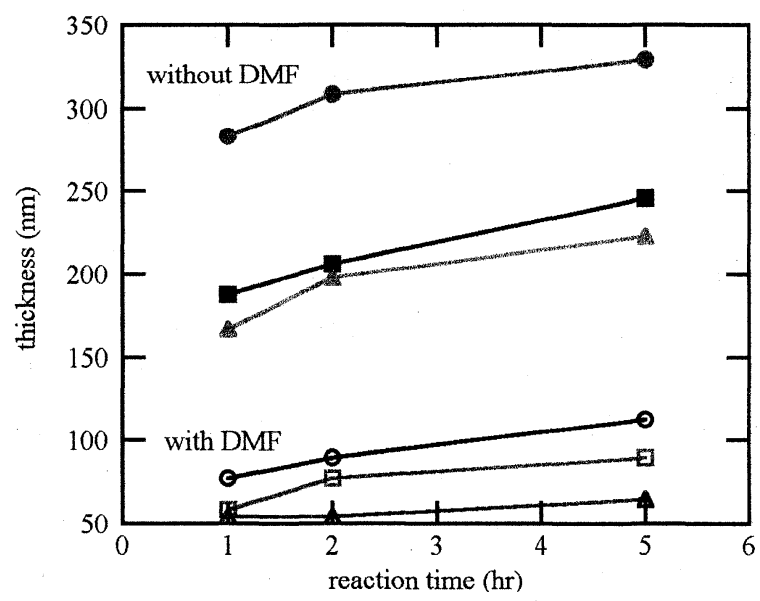

Fig. 8. Silicate layer thickness as functions of reaction time.

TEOS:EtOH: $\mathrm{H}_{2} \mathrm{O}: \mathrm{HCl}=1: 4: 4: 0.03$, drawing rate $1.0 \mathrm{~mm} / \mathrm{s}$

TEOS:EtOH: $\mathrm{H}_{2} \mathrm{O}: \mathrm{HCl}=1: 4: 8: 0.03$, drawing rate $1.0 \mathrm{~mm} / \mathrm{s}$

$\triangle \Delta$ TEOS:EtOH:H $\mathrm{H}_{2}: \mathrm{HCl}=1: 4: 8: 0.03$, drawing rate $0.5 \mathrm{~mm} / \mathrm{s}$

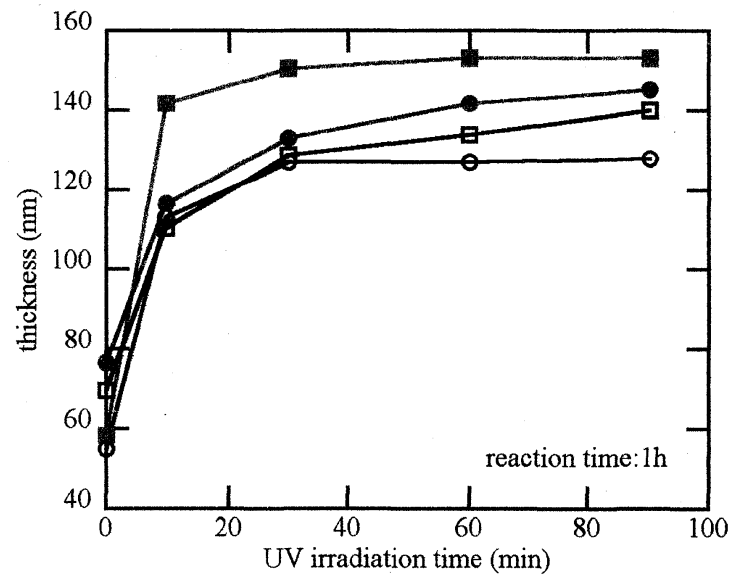

Fig. 9. Silicate layer thickness as functions of UV irradiation time.

$\square$ TEOS:EtOH:H $\mathrm{H}_{2} \mathrm{O}: \mathrm{HCl}: \mathrm{DMF}=1: 4: 4: 0.03: 1$, drawing rate $0.5 \mathrm{~mm} / \mathrm{s}$ TEOS:EtOH: $\mathrm{H}_{2} \mathrm{O}: \mathrm{HCl}: \mathrm{DMF}=1: 4: 8: 0.03: 1$, drawing rate $0.5 \mathrm{~mm} / \mathrm{s}$ TEOS:EtOH: $\mathrm{H}_{2} \mathrm{O}: \mathrm{HCl}: \mathrm{DMF}=1: 4: 4: 0.03: 1$, drawing rate $1.0 \mathrm{~mm} / \mathrm{s}$ TEOS:EtOH:H ${ }_{2} \mathrm{O}: \mathrm{HCl}: \mathrm{DMF}=1: 4: 8: 0.03: 1$, drawing rate $1.0 \mathrm{~mm} / \mathrm{s}$ 
ティング時に基板であるナイロンフィルムに付着する溶 液量が増加するためと考えられる。

\section{$3 \cdot 3$ 水蒸気透過試験}

Fig. 10 はゾルーゲル反応時間と水蒸気透過度との関 係を組成別に示す.加水分解試薬量を増加させると水蒸 気透過度が低くなることがわかる。加水分解試薬量を増 加させた場合にIR 吸収強度が低く膜厚は薄いにもかか わらず水蒸気透過度が低いのは, 水量を増加させること で系の濃度を希釈し，コーティング溶液の均一性を高め た結果, 生成シロキサンも均質な状態になるためと考え られる。一定の組成で比較してみると DMF を含む系の 方の水蒸気透過性が低くなっている．膜児の結果を考慮 すると DMF が乾燥抑制剤として働き, コーティングフ イルム表面のき裂の発生を抑制しているためと考えら れる。

Fig. 11 は水蒸気透過度と紫外線照射時間の依存性を 示している。紫外線の照射時間とともに水蒸気透過度は 徐々に低下していく．このことは紫外線により進行する 重合反応のためシロキサン量が増加し, 紫外線照射しな かった場合と比較して同じ調製条件でも基板に付着する コーティング量が多くなることが一つの原因であると考 えられる。

\section{$3 \cdot 4$ 表面モルフォロジー}

DMF を添加しない系で組成比を TEOS：EtOH： $\mathrm{H}_{2} \mathrm{O}: \mathrm{HCl}=1: 4: 4: 0.03$ にてゾル溶液を種々の反応 時間で調製し，引き上げ速度 $1.0 \mathrm{~mm} / \mathrm{s}$ で作成したコー ティング膜表面の AFM 像を Fig. 12 (a)，(b) および (c) に示す．ゾルーゲル反応時間が短い場合 (a) にはコーテ イング膜表面は滑らかであったが, 反応時間が長くなる につれ (c) 表面が徐々に粗くなっていく様子が観察され た. 反応時間が短い場合, TEOSの加水分解がすべての

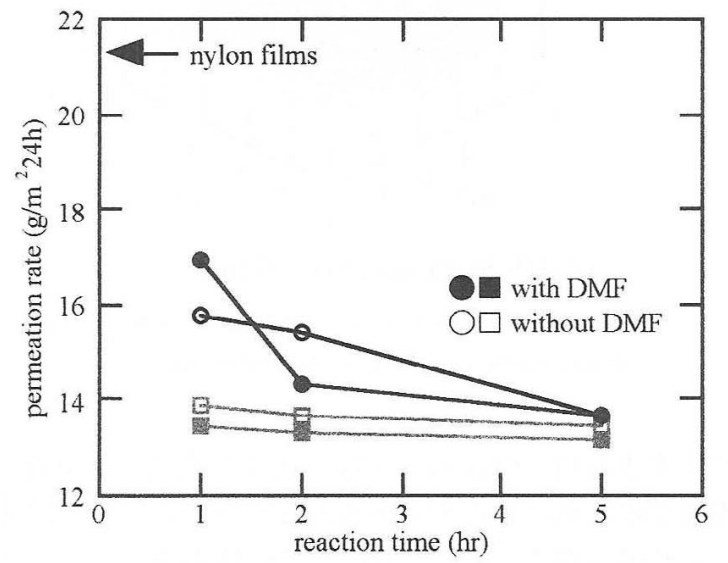

Fig. 10. Water vaper permeation rate through silicate coated nylon films as functions of sol-gel reaction time for various reaction compositions. (drawing rate $1.0 \mathrm{~mm} / \mathrm{s}$ ).

O TEOS:EtOH: $\mathrm{H}_{2} 0: \mathrm{HCi}=1: 4: 4: 0.03$

TEOS:EtOH: $\mathrm{H}_{2}^{2} 0: \mathrm{HCl}: \mathrm{DMF}=1: 4: 4: 0.03: 1$

$\square$ TEOS:EtOH: $\mathrm{H}_{2} 0: \mathrm{HCl}=1: 4: 8: 0.03$

- TEOS:EtOH:H ${ }_{2}^{2}: \mathrm{HCl}: \mathrm{DMF}=1: 4: 8: 0.03: 1$

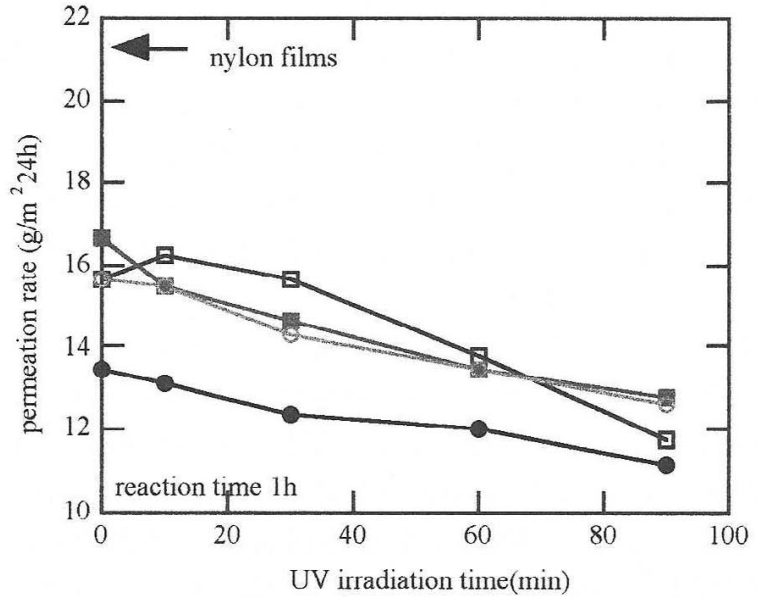

Fig. 11. Water vaper permeation rate through silicate coated nylon films as functions of UV irradiation time for various reaction compositionstime.

$\square$ TEOS:ELOH:H $\mathrm{H}_{2} \mathrm{O}: \mathrm{HCl}: \mathrm{DMF}=1: 4: 4: 0.03: 1$, drawing rate $0.5 \mathrm{~mm} / \mathrm{s}$

TEOS:EtOH:H $\mathrm{H}_{2} \mathrm{O}: \mathrm{HCl}: \mathrm{DMF}=1: 4: 8: 0.03: 1$, drawing rate $0.5 \mathrm{~mm} / \mathrm{s}$

TEOS:EtOH:H ${ }_{2}^{2} \mathrm{O}: \mathrm{HCl}: \mathrm{DMF}=1: 4: 4: 0.03: 1$, drawing rate $1.0 \mathrm{~mm} / \mathrm{s}$

TEOS:EtOH:H $\mathrm{H}_{2} \mathrm{O}: \mathrm{HCl}: \mathrm{DMF}=1: 4: 8: 0.03: 1$, drawing rate $1.0 \mathrm{~mm} / \mathrm{s}$

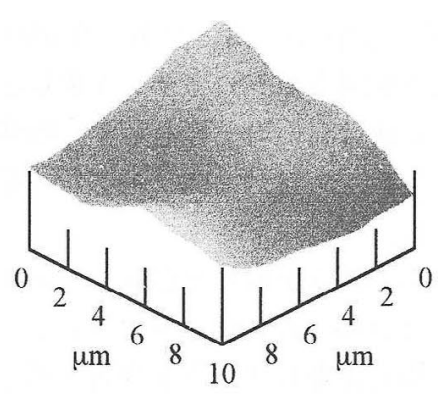

(a) reaction time $: 1 \mathrm{hr}$

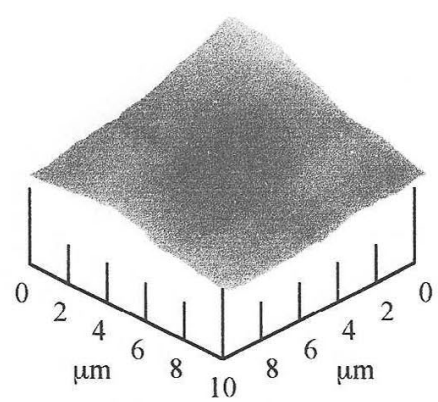

(b) reaction time $: 2 \mathrm{hr}$

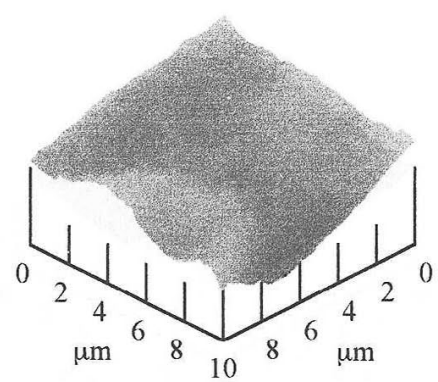

(c) reaction time $: 5 \mathrm{hr}$

Fig. 12. AFM images of surface morphology of silicate coated nylon film. 
エトキシ基でシラノールに変化するのではなく，1 つか 2 つのエトキシ基がシラノールに変化する。それらが重合 するため低分子量の鎖状ポリシロキサンとなって基板に 付着すると考えられる。一方, 反応時間が長くなると, 鎖状のポリシロキサンが徐々に 3 次元のポリシロキサン 粒子に成長し，これが付着していくため表面が粗くなっ ていったものと思われる。

Fig. 13 にはコーティング膜表面モルフォロジーに与え る DMF 添加の影響を示す。組成比は TEOS：EtOH： $\mathrm{H}_{2} \mathrm{O}: \mathrm{HCl}=1: 4: 4: 0.03$ であり, 反応時間 $1 h r$, 加 熱時間 $24 h$ である.DMF の添加により表面はより滑ら かになっている. DMF は乾燥抑制剤として乾燥時の溶 媒除去により発生する体積収縮のためのコーティング表 面のき裂を押さえる効果をもたらしているだけでなく， 系の濃度を希䣋してより均一なコーティングが作製でき る。そのためコーティング表面の均一性が向上したもの と考えられる.

Fig. 14 には 1 時間のゾルーゲル反応時間後に紫外線 照射させたコーティング溶液から作製したフィルムの表 面モルフォロジーを示す．組成比はTEOS：EtOH： $\mathrm{H}_{2} \mathrm{O}: \mathrm{HCl}=1: 4: 4: 0.03$ であり, DMF を添加してい

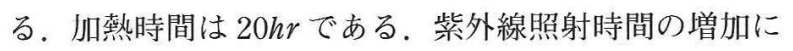
伴い重合反応が促進されシロキサン生成量が増加するに も関わらず，表面は高い均一性を示す．紫外線照射時間 が 60 ，90 分になると，わずかながら表面が荒れている様 子が観察される.

このようにDMF の添加およびゾルーゲル反応系への 紫外線照射により均一な表面モルフォロジーを有する膜 が得られた。重合が進行すると 3 次元のポリシロキサン

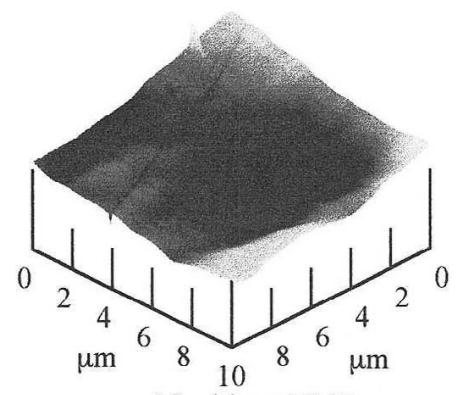

(a) without $\mathrm{DMF}$

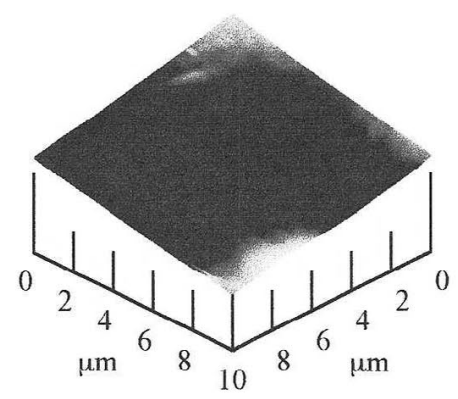

(b) with DMF

Fig. 13. AFM images of surface morphology of silicate coated nylon films obtained with and without DMF.

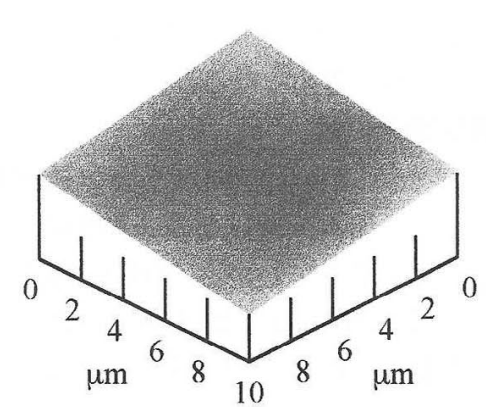

(a) UV irradiation time $: 10 \mathrm{~min}$

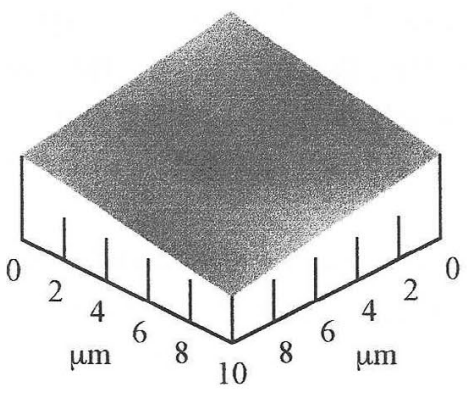

(b) UV irradiation time :30 min

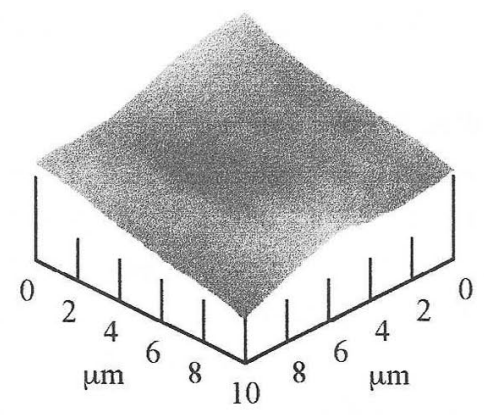

(c) UV irradiation time :60 $\mathrm{min}$

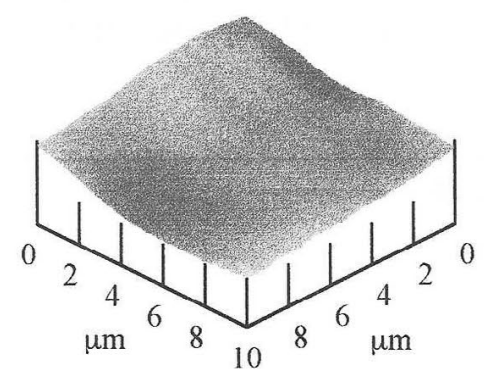

(d) UV irradiation time :90 min

Fig. 14. Effect of UV irradiation on the surface morphology of silicate coated nylon films.

が生成され圴一性が低下すると考えられるが, DMFを 添加すると系の濃度が希釈されるだけではなく, 乾燥に よる収縮が抑えられるため均一性が増加する。また紫外 線を照射すると重合反応が速くなり，生成する低分了量 の鎖状ポリシロキサンのため均一に基板表面に付着する と考えられる。これはゾルーゲル反応触媒が酸触媒のと き, 加水分解反応の反応プロセスはプロトンがエトキシ 基の酸素原子を攻撃する求電子反応 ${ }^{21)}$ であるため TEOS の官能基すべてがシラノールに変化するのに時間がかか り，重合が平行して進行するためであることが原因であ 
ると考えられる，従って紫外線を照射しない系では加水 分解, 重合反応ともに速度が低いため, TEOSの官能基 すべてがシラノールに変化し, 重合により 3 次元ポリシ ロキサンとなりこれが膜表面の不均一性を発現させてい るものと思われる.

\section{4 結}

\section{言}

ゾルーゲル反応によりナイロンフィルム上に無色透明 で表面が滑らかな酸化ケイ素コーティングが得られた。 反応時間とともに $\mathrm{SiO}_{2}$ 生成量の増加し, 膜厚も増加し たが徐々にコーティング表面が粗くなり均一なコーティ ングが困難になった．これはゾルーゲル反応系で重合が 進行し, ポリシロキサンの 3 次元網目構造が形成され, 粒状のポリシロキサンがナイロンフィルム上にコートさ れたために表面が不均一になったものと思われる.

ゾルーゲル反応系の水分率を高くすると膜の厚さは減 少するが，均一な膜が形成されるために水蒸気透過度は 低くなった。また組成比および反応時間を一定にした場 合, 引き上げ速度が大きくなるほどコーティング量が増 加した. DMF を添加した場合にもコーティング膜の厚 さは小さくなるが, 表面は均一となり水蒸気透過度は低 くなった。これは DMFの添加により系が希釈され均一 な膜が形成されただけではなく, DMF が乾燥抑制剤と して働き，乾燥時の急激な体積収縮を抑制し，クラック などの発生を抑えたためであると思われる。これらのこ とより, 酸化ケイ素膜の厚さ自身より, 酸化ケイ素膜の 均一性および完全性がフィルムのガス透過性に大きな影 響を与えているものと考えられる。

ゾルーゲル反応系に紫外線を照射した場合には, 重合 反応が促進され，低分子量の鎖状ポリシロキサンがナイ ロンフィルム上にコーティングされたため, 均一で滑ら かな酸化ケイ素膜が形成されたものと考えられる.

\section{参 考 文 献}

1）作花済夫, “ゾルーゲル法の科学” p.8 (1988) アグネ承風社.

2 ）横尾俊信, 神谷寛一, 作花済夫, 日本金属学会会報, 27 , 775 (1988).
3 ）山本雄二, 神谷寛一, 作花済夫, 窯業協会誌 90,328 (1982)

4) M. Guglielmi and S. Zenezini, J. Non-Cryst. Solid, 121, 303 (1990).

5) R. Mizutani, Y. Oono, J. Matsuoka, H. Nasu and K. Kamiya, J. Mater. Sci., 29, 5773 (1994).

6) 山根正之編, “ジルーゲル法の技術的課題とその対策” p.251（1990）アイピーシー.

7) G. Philip and H. Schmidt, J. Non-Cryst. Solid, 63, 283 (1984).

$8)$ H. Schmidt, J. Sol-Gel Sci. and Tech., 1, 217 (1994).

9) M. Kawasaki, Y. Kimura, T. Iwasaki and H. Yamane, Sen-I Gakkaishi, 54, 577 (1998).

10) M. Kawasaki, Y. Kimura, T. Iwasaki and H. Yamane, Sen-I Gakkaishi, 56, 26 (2000).

11) C. J. Brinker, A. J. Hurd, P. R. Shunk, G. C. Frye and C. S. Ashley, J. Non-Cryst. Solid, 147\&148, 424 (1992).

12) S. Maekawa and T. Ohishi, J. Non-Cryst. Solids, 169, 207 (1994).

13) S. Maekawa, K. Okude and T. Ohishi, J. Sol-Gel Sci. Tech., 2, 497 (1994).

14）沢木 司, “真空技術講座 10 , 真空蒸着” p.133, p.239 （1965）日刊工業新聞社.

15) K. Iwashita, K. Tadanaga and T. Minami, J. Applied Poly. Sci., 61, 2173 (1996).

16） JIS Z208 日本規格協会（1976）.

17）高分子学会編, “高分子と水” p.122（1995）共立出版.

18) S. Sakka and K. Kamiya, Proc. of Intern. Symp. of Factors in Densification and Sinter. of Oxide and Non-Oxide Ceramics, Japan, p.101 (1978).

19）野田敏男, 中山永一, “真空”, 7,5 (1962).

20) E. Ritte, Optica Acta, 9, 197 (1962).

21) K. K. Keefer, "Better Cerramics through Chemistry", ed. C. J. Brinker, D. E. Clark and D. R. Ulrich, p.15 (1984) North Holland, New York. 